\title{
AKIBAT HUKUM WANPRESTASI DALAM PERJANJIAN WARALABA (FRANCHISE) PEMPEK FARINA DI KOTA DENPASAR
}

\author{
Kenneth De Lara Lim, I Nyoman Putu Budiartha, Ni Made Puspasutari Ujianti \\ Fakultas Hukum Universitas Warmadewa, Denpasar - Bali, Indonesia
}

\begin{abstract}
Abstrak
Waralaba adalah hubungan usaha antara pemilik merek dengan pihak lain yang memberikan izin dari pemakaian merek dalam jangka waktu tertentu. Jika para pihak tidak menaati isi dalam perjanjian waralaba, pihak yang dirugikan dapat menuntut. Waralaba yang beroperasi di Denpasar adalah Pempek Farina. Pempek Farina merupakan bisnis waralaba yang bergerak pada industri makanan siap saji. Tujuan penelitian ini yaitu untuk mendeskripsikan bentuk perjanjian waralaba Pempek Farina di Kota Denpasar dan menganalisis akibat hukum bagi pihak penerima waralaba jika melanggar perjanjian waralaba Pempek Farina. Tujuan penelitian ini untuk mengetahui bentuk perjanjian dan mengetahui akibat hukum bagi pihak penerima waralaba jika melanggar perjanjian waralaba. Metode penelitian yang digunakan adalah penelitian empiris dengan pendekatan sosiologis. Hasil penelitian menunjukan bahwa bentuk perjanjian waralaba Pempek Farina merupakan bentuk perjanjian dibawah tangan, akibat yang timbul bila pihak penerima waralaba melakukan wanprestasi dalam perjanjian maka perjanjian yang telah dibuat dapat berakhir. Dengan ketentuan Pasal 1266 dan Pasal 1267 KUHPer pihak pemberi waralaba akan membatalkan perjanjian dan meminta penerima waralaba untuk menghentikan penjualan produk pemberi waralaba.
\end{abstract}

Kata Kunci: Akibat Hukum, Wanprestasi, Waralaba

\begin{abstract}
Franchise is a business relationship between a brand owner and another party that gives permission for the use of the mark within a certain period. If the parties do not comply with the contents of the franchise agreement, the injured party can sue. The franchise operating in Denpasar is Pempek Farina. Pempek Farina is a franchise business that is engaged in the fast food industry. The purpose of this study is to describe the form of the Pempek Farina franchise agreement in Denpasar and analyze the legal consequences for the franchisee if it violates the Pempek Farina franchise agreement. The purpose of this study is to determine the form of the agreement and determine the legal consequences for the franchisee if it violates the franchise agreement. The research method used is empirical research with a sociological approach. The results showed that the form of the Pempek Farina franchise agreement is a form of underhand agreement, the result of which arises when the franchisee defaults on the agreement, the agreement that has been made may expire. With the provisions of Article 1266 and Article 1267 of the Criminal Code the franchisor will cancel the agreement and ask the franchisee to stop selling the product of the franchisor.
\end{abstract}

Keywords: Default; Franchise; Legal Consequences

\section{PENDAHULUAN}

Salah satu bisnis yang banyak ditemui dan berkembang di Indonesia adalah bisnis waralaba. Waralaba adalah suatu kerjasama usaha atau pun bisnis antara pemilik merek usaha dengan pihak lain yang memberikan izin untuk pemakaian merek usaha, dalam jangka waktu yang sudah ditentukan atau sudah disepakati (Mendelson, 2013). Usaha waralaba bisa terjadi diberbagai bentuk bidang yaitu pendidikan, pelayanan kesehatan, makanan, dan lain - lain. Bisa dikatakan juga bahwa waralaba dapat diartikan sebagai suatu cara untuk melakukan pemasaran jasa dan atau barang, dimana pemilik waralaba atau pemberi waralaba memberikan kepada pihak lain atau penerima waralaba berupa hak yang istimewa untuk melaksanakan suatu cara dan juga sistem usaha atau bisnis dengan cara yang sudah ditentukan, 
contohnya sudah ditentukan tempat dan selama waktu perjanjian kerjasama. Pada mulanya istilah waralaba tidak ada atau tidak diketahui didalam Hukum Indonesia, hal ini bisa dimengerti karena lembaga waralaba sendiri sejak awal tidak terdapat dalam tradisi bisnis atau usaha masyarakat di Indonesia. Namun karena perkembangan jaman yang maju diberbagai bidang usaha dan juga bisnis, maka waralaba ini kemudian muncul kedalam tradisi bisnis usaha dan masuk kedalam hukum masyarakat di Indonesia.

Pengertian waralaba dapat dilihat dari berbagai macam pandangan. Dari pandangan pemilik waralaba, waralaba dapat diartikan sebagai kelompok hak milik intelektual. Dari pandangan pewaralaba, waralaba diartikan sebagai suatu paket usaha sedangkan dari sudut pandang hukum waralaba yaitu perjanjian kerjasama atau suatu bentuk kontrak kerjasama. Sedangkan menurut pandangan masyarakat umum dan juga pemerintah waralaba dapat dipandang sebagai suatu hubungan kerjasama usaha (Simatupang, 2003). Bisnis waralaba merupakan bisnis yang sangat menjanjikan. Dalam perekonomian Indonesia sangat cocok untuk melakukan bisnis waralaba karena bisnis waralaba memiliki kegagalan yang kecil dan memiliki pertumbuhannya yang sangat pesat. Semakin meningkatnya bisnis atau usaha waralaba sebagai suatu sistem distribusi atau pemasaran jasa dan barang menjadikan bisnis waralaba tersebut populer. Karena efektifnya sistem pemasaran melalui sistem waralaba keberadaannya pun dianggap mampu memasarkan suatu bentuk produk keseluruh Indonesia. Karena bisnis atau usaha waralaba ini menjanjikan dalam kata lain berpeluang besar di Indonesia menyebabkan waralaba asing dan juga waralaba lokal mulai bertambah dan meningkat dengan sangat pesat. Untuk memulai bisnis bagi seorang pemula bentuk waralaba ini sangat cocok untuk memulai sebuah usaha dalam dunia bisnis.

Bisnis yang berkembang saat ini perlu dilindungi hukum untuk melindungi masyarakat didunia bisnis tidak terkecuali bisnis waralaba. Hal ini berguna untuk melindungi pihak - pihak dalam bisnis waralaba. Keberadaan hukum dalam bisnis bertujuan untuk memberi kepastian hukum dan menciptakan rasa keadilan dalam kehidupan bermasyarakat, sehingga menimbulkan ada pertanggungjawaban bila terjadi dampak yang muncul dari bisnis tersebut. Untuk menanggulangi sesuatu hal yang tidak diinginkan oleh orang - orang atau pun pebisnis yang mau masuk didalam dunia bisnis lebih baik memahami terlebih dahulu hukum bisnis seperti apa yang akan dijalankan untuk menciptakan manfaat bagi masyarakat umum dalam hal menyejahterakan dan juga memberikan manfaat bagi diri atau individu agar usaha yang dijalankan berjalan sebagaimana mestinya dengan baik (Naihasy, 2005). Artinya, waralaba memiliki hal penting bagi pemberi waralaba atau pengusaha dan juga mitra kerjasama atau penerima waralaba dalam masalah perlindungan hukum dan kepastian hukum oleh para pihak.

Dalam bisnis waralaba dibutuhkan ada suatu perjanjian. Perjanjian waralaba adalah suatu bentuk perlindungan hukum dari pihak - pihak yang melakukan perbuatan yang dilarang atau merugikan salah satu pihak. Bila terjadi suatu pelanggaran dalam perjanjian waralaba, pihak yang merasa dirugikan bisa melakukan penuntutan kepada pihak yang melakukan pelanggaran dengan hukum yang berlaku saat ini. Perjanjian tersebut tidak hanya diperlukan untuk perjanjian waralaba berskala internasional, namun juga berlaku untuk bisnis waralaba berskala nasional. Salah satu waralaba berskala nasional yang beroperasi di Denpasar adalah Pempek Farina. Pempek Farina merupakan bisnis waralaba yang bergerak pada industri makanan dimana produk utama dari Pempek Farina adalah Pempek. Pempek Farina merupakan usaha atau bisnis dibidang industri makanan siap saji dengan penjualan menggunakan konter seperti: konter tetap, kafe \& restoran.

Peraturan atau perjanjian yang menjadi salah satu pasal dalam perjanjian tersebut sering dilanggar oleh pihak mitra yaitu seperti contoh pihak mitra kerja sama yang menggunakan konter tetap tidak membayar royalti per bulan kepada Pempek Farina namun masih berjualan dengan nama Pempek Farina. Selain itu terjadi permasalahan dimana terdapat beberapa konter tetap yang menggunakan produk selain produk dari Pempek Farina yang dijual kepada konsumen. Hal tersebut termasuk kedalam wanprestasi dari hasil perjanjian yang terjadi pada waralaba Pempek Farina.

Terkait dengan permasalahan yang dikaji dalam penelitian ini, ada beberapa peneliti yang telah meluncurkan hasil penelitian dengan objek penelitian yang beberbeda. Pertama, (Katrinasari \& Hadi, 2017) mengatakan bwha perjanjian waralaba merupakan salah satu aspek perlindungan hukum. Hal ini dikarenakan perjanjian dapat menjadi dasar hukum yang kuat untuk menegakkan perlindungan hukum rahasia dagang dan bagi para pihak. Kedua, (Lasamahu, 2017) menyatakan bahwa gugatan wanprestasi 
yang sedianya hanyalah gugatan yang didasarkan pada hubungan kontraktual sedangkan gugatan PMH (Perbuatan Melawan Hukum) yang sedianya hanyalah gugatan yang didasarkan pada tidak adanya hubungan kontraktual, yang dikenal dengan sebutan teori klasik hukum kontrak, tidak lagi berlaku secara mutlak. Perkembangan dalam praktik putusan pengadilan telah menunjukan pergeseran teori ke arah dimana adanya wanprestasi dalam suatu perjanjian tidak menghalangi Penggugat untuk mengajukan gugatan $\mathrm{PMH}$, teori ini d isebut teori modern hukum kontrak. Ketiga, penelitian yang dilakukan oleh (Klick, Kobayashi, \& Ribstein, 2011) mengungkapkan bahwa Beberapa undang-undang pemberhentian, khususnya yang membatasi pekerjaan kontraktual, secara signifikan memengaruhi aktivitas waralaba, sementara yang tidak membatasi penghindaran memiliki efek ambigu. Berdasarkan deskripsi tersebut di ats, penelitian baru ini bertujuan untuk mendeskripsikan bentuk perjanjian waralaba Pempek Farina di Kota Denpasar dan menganalis akibat hukum bagi pihak penerima waralaba jika melanggar perjanjian waralaba Pempek Farina.

\section{METODE PENELITIAN}

Penelitian ini didesain dengan menggunakan metode penelitian empiris dengan pendekatan hukum sosiologis (Amirrudin \& Asikin, 2012). Lokasi penelitian ini dilakukan di salah satu cabang rumah makan Pempek Farina yang beralamat di Jalan Tukad Batang Hari No.15, Denpasar Selatan. Dipilihnya lokasi tersebut karena Pempek Farina tersebut merupakan usaha waralaba yang sudah berjalan cukup lama dan melakukan ikatan perjanjian kerjasama dengan pemberi waralaba. Teknik pengumpulan data yang digunakan adalah wawancara terstruktur yaitu pertanyaan telah disusun terlebih dahulu kemudian ditanyakan kepada informan. Informan yang diwawancarai antara lain orang-orang yang terlibat dalam praktik perjanjian waralaba Pempek Farina di Denpasar.

Setelah data terkumpul, kemudian dianalisi dan diolah dengan cara menyusun data - data dalam paragraf sehingga diperoleh gambaran secara utuh. Kemudian, dideskripsikan dalam bentuk kata-kata. Ada dua jenis data yang digunakan dalam penelitian ini adalah data primer dan data sekunder. Data primer diperoleh melalui wawancara kepada pihak Pempek Farina. Wawancara menyangkut hal - hal mengenai implementasi perlindungan hukum bagi pemberi waralaba dalam perjanjian waralaba (Pempek Farina di Kota Denpasar). Sedangkan data sekunder adalah data yang diperoleh dari sumber-sumber antara lain yaitu buku-buku hukum maupun buku lain yang terkait, perundangundangan, surat kabar, majalah, dan internet (dari website resmi). Adapun perundang-undangan yang terkait adalah sebagai berikut: 1. Kitab Undang-Undang Hukum Perdata (Kebablijk Wetboek voor Indonesie) 2. Peraturan Pemerintah Nomor 42 Tahun 2007 tentang Waralaba 3. Peraturan Menteri Perdagangan Nomor 31 Tahun 2008 tentang Penyelenggaraan Waralaba.

\section{HASIL PENELITIAN DAN PEMBAHASAN Bentuk Perjanjian Waralaba Pempek Farina Di Kota Denpasar}

Bentuk perjanjian atau kontrak dapat dibagi menjadi dua jenis yang pertama bentuk perjanjian tertulis dan yang kedua bentuk tidak tertulis atau lisan. Bentuk perjanjian tertulis merupakan perjanjian yang dibuat oleh para pihak dalam bentuk tulisan, sedangkan bentuk perjanjian tidak tertulis atau lisan merupakan perjanjian yang dibuat oleh para pihak dalam bentuk atau wujud lisan saja. Perjanjian lisan merupakan sebuah perjanjian yang telah disetujui kedua belah pihak secara lisan. Berbeda dengan perjanjian tertulis, perjanjian lisan tidak menjelaskan secara detail mengenai ketentuan dan hal - hal yang telah disetujui dalam sebuah dokumen. Namun, selayaknya perjanjian tertulis, perjanjian lisan tetap dianggap sah dimata hukum dan tidak menghilangkan baik hak dan kewajiban dari pihak yang bersepakat. Berhubungan dengan bentuk perjanjian waralaba ini, Pasal 4 ayat (1) Peraturan pemerintah tentang waralaba, mengharuskan bahwa perjanjian waralaba dilaksanakan menurut atau berdasarkan perjanjian tertulis oleh pemberi waralaba dengan penerima waralaba dengan memerhatikan hukum yang berlaku di Indonesia. Berdasarkan ketentuan Pasal 4 ayat (1) Peraturan Pemerintah tentang waralaba ini jelaskan bahwa apabila pemberi dan penerima waralaba telah sepakat atau mengikatkan diri dalam sebuah perjanjian maka perjanjian waralaba harus dibuat didalam bentuk perjanjian tertulis. Bentuk perjanjian 
tertulis terdapat tiga bentuk yaitu perjanjian dibawah tangan, perjanjian dengan saksi notaris untuk melegalisir tanda tangan para pihak, perjanjian yang dibuat dihadapan dan oleh notaris (Salim, 2008).

Jika dihubungkan dengan pendapat Salim ketentuan bentuk perjanjian waralaba dalam Pasal 4 ayat (1) Peraturan pemerintah tentang waralaba diatas tidak menjelaskan bagaimana bentuk perjanjian tertulis yang disebutkan, demikian dengan situasi seperti ini tentu bentuk perjanjian waralaba yang ada dapat berbentuk 3 jenis yaitu perjanjian waralaba dengan bentuk perjanjian dibawah tangan yang ditanda tangani oleh pihak yang bersangkutan saja, perjanjian waralaba dengan bentuk perjanjian dihadapan notaris dan disaksikan untuk melegalisir tanda tangan para pihak saja dan perjanjian waralaba dengan bentuk perjanjian yang dibuat dihadapan notaris dan dibuat oleh notaris dalam bentuk akta notariil.

Bentuk perjanjian waralaba Pempek Farina yang ada di kota Denpasar merupakan bentuk perjanjian waralaba dibawah tangan, perjanjian dibawah tangan adalah perjanjian yang dibuat oleh para pihak yang berkepentingan saja dan tidak melibatkan pejabat yang berwenang dan format penulisan perjanjian dibawah tangan juga tidak dijelaskan secara jelas dalam peraturan perundang - undangan. Contohnya bentuk perjanjian sewa - menyewa. Walaupun bisa dan dapat digunakan sebagai bukti, kekuatan untuk pembuktian perjanjian dibawah tangan sangat jauh berbeda dengan akta otentik, dan tidak bisa sangat sempurna kekuatan bukti akta otentik. Perjanjian dibawah tangan tidak harus memerlukan pejabat berwenang dibidangnya sesuai aturan hukum, karena perjanjian ini dapat dibuat oleh pejabat yang tidak ditunjuk secara hukum, contohnya oleh para pihak dalam perjanjian yang dibuatnya sendiri. Karena perjanjian dibawah tangan tidak dibuat oleh pejabat yang berwenang, maka dari sebaiknya pembuatan dan penandatanganan akta ini turut menghadirkan saksi. Hal ini dilakukan untuk memperkuat pembuktian karena adanya saksi yang menyaksikan perbuatan hukum tersebut (Asikin, 2015). Jadi, pihak yang ingin menyangkal tidak bisa menyangkalnya karena sudah ada saksi yang memenuhi syarat dalam perbuatan hukum atau cakap secara hukum.

\section{Akibat hukum bagi pihak penerima waralaba jika melanggar perjanjian waralaba pempek farina di Kota Denpasar}

Akibat hukum yang timbul jika melanggar atau melakukan wanprestasi dalam perjanjian waralaba. Sebelum membahas akibat hukumnya perlu diketahui definisi wanprestasi secara umum adalah tidak melakukannya kewajiban atau prestasi sebagaimana kewajiban yang diberikan dalam perjanjian atau kontrak oleh pihak - pihak yang dinyatakan dalam perjanjian atau kontrak yang sudah dibuat (Efendi, 2016). Adapun bentuk pelanggaran yang terdapat didalam perjanjian waralaba dapat diketahui baik dari penerima waralaba maupun dari pihak pemberi waralaba adalah, pelanggaran atau wanprestasi dari penerima waralaba bisa berupa terlambat membayar biaya waralaba (tidak tepat waktu), berbuat sesuatu yang dilarang diperbuat oleh penerima waralaba, berbuat atau melakukan ketentuan pelayanan yang tidak sesuai prosedur sistem perjanjian waralaba yang telah diatur dalam perjanjian, tidak mengembalikan Hak Atas Kekayaan Intelektual setelah berjanjian sudah berakhir, menjadi pesaing dan berkompetisi dengan membuat bisnis baru dengan menggunakan nama atau merek yang baru tetapi jenis bisnis yang sejenis yang sudah diberikan oleh penerima waralaba sebelumnya. Wanprestasi dari pemberi waralaba yaitu tidak menjalankan pembinaan terhadap penerima waralaba sesuai dengan yang sudah diperjanjikan dalam perjanjian waralaba, tidak mendukung dan memberikan bantuan berupa fasilitas yang memungkinkan sistem waralaba berjalan dengan sebagaimana mestinya, tidak membantu penerima waralaba dalam keadaan kesulitan yang sedang dihadapi ketika melaksanakan usaha waralabanya.

Pihak pemberi waralaba harus menjalankan segala kewajiban didalam pelaksanaan perjanjian yang berlaku, adapun pelanggaran yang dapat dilakukan pihak pemberi waralaba adalah tidak memberikan hak kepada pihak penerima waralaba sebagaimana dijelaskan didalam perjanjian waralaba Pempek Farina. Pada perjanjian waralaba Pempek Farina di Kota Denpasar didalam perjanjian kerjasama Pasal 9 ayat (2) di katakan bahwa pihak pertama berhak melakukan pemeriksaan, pengawasan kepada pihak kedua (mitra) untuk memastikan dilaksanakannya kewajiban-kewajiban mitra berdasarkan perjanjian tersebut. Apabila menurut penilaian pihak pertama, mitra tidak melaksanakan kewajibannya berdasarkan perjanjian, maka pihak pertama akan memberikan peringatan tertulis dan mitra berkewajiban untuk memperbaiki dalam jangka waktu yang ditentukan dalam peringatan tersebut. Apabila mitra tetap tidak dapat memperbaiki 
dalam waktu yang sewajarnya menurut penilaian pihak pertama, maka dalam jangka waktu 30 hari sejak diterimanya peringatan terakhir, dengan melepaskan ketentuan pasal 1266 dan pasal 1267 Kitab undang undang hukum perdata pihak pertama akan membatalkan perjanjian tersebut dan meminta mitra untuk menghentikan penjualan produk kepada konsumen serta mitra tidak akan mendapatkan kompensasi dalam bentuk apa pun dari pihak pertama.

Pihak kedua selaku penerima waralaba harus menjalankan segala kewajiban dalam pelaksanaan perjanjian yang berlaku, pelanggaran yang dapat terjadi oleh pihak kedua apabila pihak kedua tidak melaksanakan kewajiban seperti tidak mengikuti peraturan yang sudah dibuat dalam perjanjian waralaba Pempek Farina baik dari hak dan kewajiban, pembiayaan, lokasi waralaba, maupun pelaksanaan ketentuan yang berlaku didalam perjanjian waralaba Pempek Farina dan dengan adanya suatu pelanggaran didalam suatu perjanjian yang telah dibuat maka dapat berakhir pula suatu perjanjian yang telah disepakati.

\section{SIMPULAN DAN SARAN}

1. Simpulan

Bentuk perjanjian waralaba Pempek Farina di Kota Denpasar merupakan bentuk perjanjian dibawah tangan, perjanjian dibawah tangan adalah perjanjian yang dibuat oleh para pihak saja tanpa melibatkan pejabat yang berwenang, namun demikian perjanjian dibawah tangan ini tetap dianggap sah di mata hukum dan tidak menghilangkan baik hak dan kewajiban dari kedua belah pihak, mengenai isi dari perjanjian Pempek Farina, perjanjian Pempek Farina memiliki segala ketentuan yang berlaku dalam menjalankan waralaba serta memberikan tindakan hukum bagi para pihak yang tidak melakukan semua ketentuan yang ada didalam perjanjian, perjanjian tersebut menjadi suatu pedoman agar waralaba Pempek Farina tetap dapat berjalan dengan baik didalam sistem hukum maupun segi penjualannya.

Akibat yang timbul apabila pihak penerima waralaba melakukan wanprestasi didalam perjanjian waralaba Pempek Farina di Kota Denpasar, menjelaskan apabila pihak mitra melanggar ketentuan yang berlaku dari segi hak dan kewajiban, maka perjanjian yang telah disepakati dapat berakhir. Dengan melepaskan ketentuan Pasal 1266 dan Pasal 1267 Kitab undang - undang hukum perdata pihak pemberi waralaba akan membatalkan perjanjian kerjasama dan meminta pihak penerima waralaba untuk menghentikan penjualan produk pihak pemberi waralaba.

\section{Saran}

Dengan melihat perkembangan dan kemajuan waralaba di zaman sekarang kiranya pemerintah mampu memberikan suatu pengaturan hukum mengenai waralaba yang lebih baik dikhawatirkan adanya masalah - masalah yang ditimbulkan dari perjanjian waralaba yang hanya mengikat para pihak juga peraturan pemerintah No. 42 Tahun 2007 mengenai waralaba yang hanya mempunyai peraturan yang bersifat lebih rendah didalam peraturan perundang - undangan dibandingkan dengan undang - undang yang merupakan suatu peraturan yang tertinggi didalam hierarkinya diharapkan agar kiranya peraturan mengenai waralaba yang sekarang ini dapat dikodifikasi menjadi suatu peraturan yang lebih tinggi lagi sesuai hierarki perundang - undangan di Indonesia. Hendaknya pemerintah bisa memperbarui peraturan waralaba yang ada sekarang ini agar dapat memberikan kepastian hukum dan perlindungan hukum bagi pihak penerima waralaba dan pihak pemberi waralaba. Kita membutuhkan kekuatan hukum yang membantu dibisnis waralaba agar bisnis yang saat ini sedang berkembang pesat bisa ke kondisi yang lebih baik lagi. Sistem waralaba merupakan kerjasama bisnis yang saling menguntungkan jadi merupakan kebutuhan dari pihak penerima waralaba dan juga pihak pemberi waralaba dalam mengembangkan usahanya dan juga mempunyai kepentingan yang sama.

\section{DAFTAR PUSTAKA}

Amirrudin, \& Asikin, Z. (2012). Pengantar Metode Penelitian hukum,. Jakarta: PT. Raja Grafindo Persada.

Asikin, Z. (2015). Hukum Acara Perdata di Indonesia. Jakarta: Prenada Media Group.

Efendi, J. (2016). Kamus Istilah Hukum Populer. Jakarta: Kencana. 
Katrinasari, B., \& Hadi, H. (2017). Tinjauan Hukum Terhadap Wanprestasi Royalty Rahasia Dagang dalam Perjanjian Waralaba, $V(1), 85-94$.

Klick, J., Kobayashi, B. H., \& Ribstein, L. E. (2011). The Effect of Contract Regulation: The Case of Franchising. SSRN Electronic Journal, 168(1999), 38-53.

Lasamahu, F. R. (2017). Perlindungan Hukum Terhadap Franchisee Dalam Perjanjian W Aralaba (Studi Kasus: Analisis Putusan Pengadilan Antara Pt. Lingkar Natura Inti Dan Natasha Kasakeyan). Jurnal Hukum \& Pembangunan, 36(3), 307.

Mendelson, M. (2013). Petunjuk Praktis Bagi Franchisor dan Franchise. Jakarta: IPPM.

Naihasy, S. (2005). Hukum Bisnis (Business Law). Yogyakarta: Mid Pustaka.

Salim. (2008). Hukum Perjanjian, Teori dan Praktik Penyusunan Perjanjian. Jakarta: Sinar Gafika.

Simatupang, R. B. (2003). Aspek Hukum Dalam Bisnis. Jakarta: PT. Rineka Cipta. 